\title{
Phytochemical Screening, Total Phenolic and Antioxidant Activity of Numerous Extracts from Leaves and Bark of Bauhinia rufescens Lam
}

\author{
Seid Ali Mahamat' ${ }^{1}$ Niang Lahat ${ }^{2,3}$, Ayessou Nicolas Cyrille ${ }^{2,3^{*}}$, Cisse Mady ${ }^{2,3}$, Diop Codou Mar ${ }^{2,3}$ \\ ${ }^{1}$ Adam Barka University, Abeche, Tchad \\ ${ }^{2}$ Water, Energy, Environment and Industrial Processes Laboratory (LE3PI), ESP-UCAD, Dakar, Sénégal \\ ${ }^{3}$ Center for Studies on Food Safety and Functional Molecules (CESAM-RESCIF), ESP-UCAD, Dakar, Sénégal \\ Email: ^nayessou@yahoo.fr, *nicolas.ayessou@ucad.edu.sn
}

How to cite this paper: Mahamat, S.A., Lahat, N., Cyrille, A.N., Mady, C. and Mar, D.C. (2021) Phytochemical Screening, Total Phenolic and Antioxidant Activity of Numerous Extracts from Leaves and Bark of Bauhinia rufescens Lam. Food and Nutrition Sciences, 12, 544-556.

https://doi.org/10.4236/fns.2021.126041

Received: May 15, 2021

Accepted: June 18, 2021

Published: June 21, 2021

Copyright $\odot 2021$ by author(s) and Scientific Research Publishing Inc. This work is licensed under the Creative Commons Attribution International License (CC BY 4.0).

http://creativecommons.org/licenses/by/4.0/

\begin{abstract}
Researches for natural antioxidants that play an important role in the prevention of diseases linked to free radicals have increased in recent years. In this study, antioxidant activity of Bauhinia rufescens Lam which is a medicinal plant was investigated. The methanol extract, acetone extract and water extract of leaf and trunk bark had antioxidant activity. Three methods were used: 2,2-diphenyl-1picryl-hydrazyl (DPPH), 2,2'-Azino-bis-(3-ethylbenzoth iazoline-6-sulfonic acid) (ABTS) and ferric ion reducing power (FRAP) by spectrophotometry. Phytochemical screening was carried out followed by the quantification of the total phenolic by the Folin-Ciocalteu method. The analysis of variance (ANOVA) with the STATISTICA 7.1 software revealed significant differences $(\mathrm{p}<0.05)$. Percentage inhibition (PI) and $\mathrm{IC}_{50}$ of the extracts were obtained using the OriginPro 8.5 software. These tests show that the bark is as rich in total phenolic as the leaves. The DPPH test shows that at $2.5 \mathrm{mg} / \mathrm{ml}$, the bark and the leave have similar activity. Bark has a percentage inhibition (PI) of $86.55 \% \pm 0.026 \%$ compared to the leave which PI is $85.63 \%$ $\pm 0.02 \%$. As for the ABTS test, the bark extract reached its maximum activity at $2.5 \mathrm{mg} / \mathrm{ml}$ with a PI of $99.81 \% \pm 0.012 \%$ compared to the leaf extract which has a PI of $99.61 \% \pm 0.025 \%$. The best $\mathrm{IC}_{50}$ of the extracts obtained with the $\mathrm{DPPH}$ radical is $0.139 \pm 0.001 \mathrm{mg} / \mathrm{ml}$ (hydro-acetonic), $0.354 \pm 0.001 \mathrm{mg} / \mathrm{ml}$ (hydromethanolic) and $0.840 \pm 0.001 \mathrm{mg} / \mathrm{ml}$ (aqueous) on the bark. With ABTS test, it was obtained $0.351 \pm 0.001 \mathrm{mg} / \mathrm{ml}$ (hydro-acetone; bark), $0.403 \pm 0.001$ $\mathrm{mg} / \mathrm{ml}$ (hydro-acetone; leaves) and $0.474 \pm 0.001 \mathrm{mg} / \mathrm{ml}$ (aqueous; bark). The reducing power of the leaves is slightly higher than that of the bark. Standard of ascorbic acid, has a PI of $94.86 \pm 0.008 \%$ with an $\mathrm{IC}_{50}$ of $0.213 \pm 0.001$ $\mathrm{mg} / \mathrm{ml}$. Thus, it is easy to conclude that the bark of Bauhinia rufescens has a better activity than the leaves and the alcoholic extracts have given better re-
\end{abstract}


sults than the aqueous extract.

\section{Keywords}

Bauhinia rufescens Lam, Total Phenolic, Antioxidant Activity

\section{Introduction}

The use of plants by humans is very old, to fight against diseases linked to free radicals such as asthma, cancer and diabetes and degenerative diseases [1] [2]. Plants, especially medicinal herbs, have been used for the prevention and/or treatment of several diseases since very old times [3]. The use of herbal medicine as a primary source for healthcare is the highest in the developing countries, which constitute about $80 \%$ of the world population [4]. It constitutes a medicine and a traditional pharmacopoeia. Among all the chemical constituents of plants, phenolic compounds occupy an important place with several properties such as antioxidant activity. The high cost of medicines, the inaccessibility of health care and the effectiveness and availability of medicinal plants are pushing populations towards herbal medicine [5]. In addition, many diseases including diabetes are treated satisfactorily and at a lower cost by medicinal plants thanks to the active substances they contain [6]. Antioxidant is a family of substances neutralizing the free radical and thus preventing the occurrence of diseases associated with oxidative stress [7]. These radicals are involved in oxidative stress through the antioxidant defense mechanism [8]. The best-known natural antioxidant is ascorbic acid, phenolic compounds and atocopherol [9]. Traditional herbal remedies and a balanced diet were the main sources of antioxidant that can fight free radical damage [10]. In this context, we are interested to assess an antioxidant activity of the hydro-methanolic, hydro-acetonic and aqueous extracts of the leaves and bark of Bauhinia rufescens Lam due to their known properties, their accessibility for medical treatments for certain diseases such as diabetes [11]. The active peptides isolated from the seeds of Bauhinia rufescens are used against toxicities induced by snake venom [12]. The plant was used in traditional medicine in order to control gastro-intestinal worms because of resistance developed by helminths with regard to synthetic anthelmintics available and their high cost [13]. It is a plant belonging to the Saharan savan that is used in the treatment of pathologies involving oxidative stress such as diabetes [14]. According to that, investigations are conducted to assess their antioxidant activity. This has been achieved in order to complete information and to project possible applications.

\section{Materials and Methods}

\subsection{Collection and Identification of Plant}

Leaves and bark of Bauhinia rufescens Lam were collected in May 2019, the flo- 
wering period, at Diourbel region (Senegal). The plant was identified and authenticated in botany-biodiversité laboratory, plant biology department of Cheikh Anta Diop University in Dakar. Plant leaves and bark were washed with distilled water and air-dried at room temperature in the laboratory. Dried leaves and bark were ground to a fine powder using an electric grinder (Kenwood, France). The sifted powder with $1 \mathrm{~mm}$ mesh was stored at $4^{\circ} \mathrm{C}$ in airtight jars. Thus, the powders are then subjected to two extraction methods: by infusion and by Soxhlet under reflux.

\subsection{Extraction}

Infusion was made in triplicate with boiling distilled water. The ratios were $10 \mathrm{~g}$ $( \pm 0.01 \mathrm{~g})$ of powder in $100 \mathrm{~mL}$ of solvent. After cooling, the infused product was filtered under vacuum and then stored in a sterile glass bottle tightly closed at $4^{\circ} \mathrm{C}$.

\section{Extraction under reflux}

The extraction was carried out with methanol (70\% v/v), (99.98\%, Scharlau Chemie SA, SPAIN) and acetone (70\% v/v), (99.5\%, Scharlab SL, SPAIN) on an out-let of $10 \mathrm{~g}( \pm 0.01 \mathrm{~g})$ of vegetable powder brought into contact with the solvent for two hours. After cooling, the mixture was separated using a centrifuge (Hittich, Universal $16 \mathrm{~A}$, France) at $3000 \mathrm{rpm}$ for 10 minutes then vacuum filtered on Wattman No.1 paper in order to obtain on the one hand the cake and on the other hand the filtrate consisting of the extract and the solvent. In the extracts, traces of solvent were removed using a rotary evaporator (IKA, RV10-German).

\subsection{Qualitative Phytochemical Screening}

Standard phytochemical analysis methods were used to test for the presence of phytoconstituents in the extracts. Chemical tests were carried out on hydro-acetone, hydro-methanolic and aqueous extracts using standard methods for the detection of tannins (Stiasny test followed by ferric chloride test), flavonoids (Shibata's test) [15], steroids and triterpenoids (Liebermann-Buchard test) [16] alkaloïds (Valser-Mayer and Dragendorff's reagents tests), saponins (foaming index) [17].

\subsection{Determination of Total Phenolic Content}

Total phenolic content (TPC) of the sample was estimated by the Folin-Ciocalteu reagent colorimetric method as described elsewhere slightly modified [18]. In brief, $50 \mu \mathrm{L}$ of sample diluted to $450 \mu \mathrm{L}$ with distilled water and standard was added to $2500 \mu \mathrm{L}$ of ten times diluted Folin-Ciocalteu reagent. Then, after adding $2.5 \mathrm{~mL}$ of $0.75 \%$ sodium carbonate, (all from Sigma-Aldrich Chemie, Germany), the mixtures were vortexed and incubated at $50^{\circ} \mathrm{C}$ in a water bath for 15 minutes. The samples prepared above were kept the samples pin the dark at room temperature for 30 minutes. Thereafter, the absorbance of each sample was read at $760 \mathrm{~nm}$ against the blank. Gallic acid was used for calibration 
of a standard curve. TPC was determined as gallic acid equivalents (GAE) and values were expressed as mg GAE/g dry matter (DM) of plant extract.

\subsection{Evaluation of Antioxidant Activity}

Three methods were used for the purpose: 2,2-diphenyl-1picryl-hydrazyl (DPPH), 2,2'-azino-bis-acid-(3-ethylbenzothiazoline-6-sulfonic acid) (ABTS) and ferric ion reducing power (FRAP).

\subsubsection{DPPH Radical Scavenging Assay}

The antioxidant activity was evaluated with DPPH (2, 2-diphenyl-1-pycrilhydrazyl, Sigma, chemical company, USA) by making some modifications to the method of Oliveira and al. [19]. The method is based on the ability of an extract to donate a singular electron to the radical free DPPH of dark purple color to stabilize it in DPPH of yellow-green color (Figure 1). Thus, $100 \mu \mathrm{l}$ of extracts were introduced into a test tube containing $1300 \mu \mathrm{l}$ of DPPH (0.004\% prepared in methanol). The negative control is prepared by mixing $100 \mu$ l of methanol with $1300 \mu \mathrm{l}$ of the methanolic solution of DPPH. The positive control is represented by a solution of a standard antioxidant, ascorbic acid (AnalaR NORMAPUR, Leuven, Belgium) tested at different concentrations (0.039, 0.078, 0.156, 0.313, $0.625,1.2$, and $2.5 \mathrm{mg} / \mathrm{ml}$ ) the absorbance of which was measured under the same conditions as the samples and for each concentration. The samples were kept in the dark for 15 minutes at room temperature and absorbance was measured at $517 \mathrm{~nm}$ on a UV/visible light spectrophotometer (Spectronic Genesys 8, Rochester, USA). All determinations were carried out in triplicate. Radical scavenging activity was calculated by the following formula:

$$
I(\%)=100\left(\frac{A_{c o}-A_{e x}}{A_{c o}}\right)
$$

$I(\%)=100(($ Aco - Aex $) /$ Aco $)$.

$I(\%)$ : Antioxidant activity as a percentage of inhibition of DPPH.

$A_{c o}$ : absorbance of blank sample $(\mathrm{t}=0 \mathrm{~min})$.

$A_{E x}$ : absorbance of tested extract solution $(\mathrm{t}=15 \mathrm{~min})$.

\subsubsection{ABTS Radical Cation Decolourisation Assay}

The anti-free radical activity was also evaluated by ABTS, 2,2-azinobis(3ethylbenzothiazoline-6-sul-fonic acid)diammonium salt (Sigma-Aldrich Chemie,

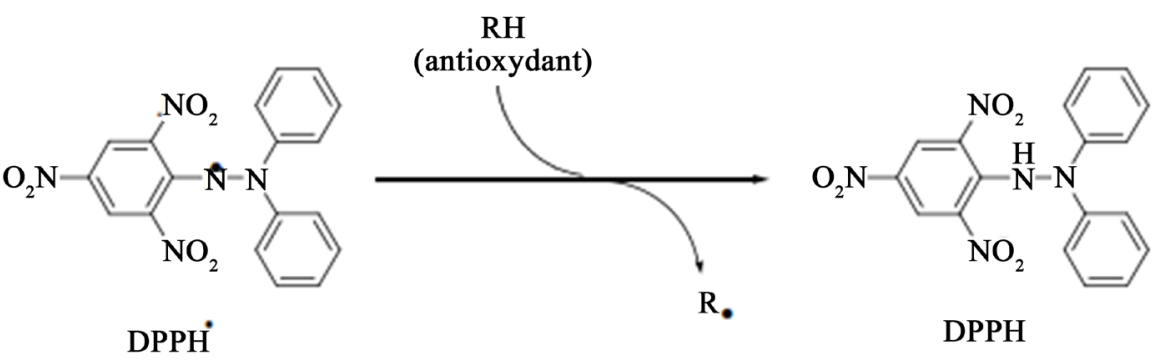

Figure 1. DPPH formation reaction from DPPH Radical and an antioxidant. 
Steinheim, Germany) radical cation decolourisation test using spectrophotometric method [20]. ABTS was dissolved in distilled water to a concentration of $7 \mathrm{nM}$. The solution of the ABTS cation radical was obtained by incubating for 12 to 16 $\mathrm{h}$ in the dark and at room temperature a mixture of equal volumes of the stock ABTS solution with a solution of potassium persulfate (99\%, Scharlab SL, Spain) at $2.45 \mathrm{nM}$ (Figure 2). ABTS cation solution was diluted with ethanol to an absorbance of $0.700 \pm 0.02$ at $734 \mathrm{~nm}$ before use. Then $1500 \mu \mathrm{l}$ of ABTS cation solution were mixed with $50 \mu \mathrm{l}$ of extract solution or reference (ascorbic acid) at different concentrations (same of the DPPH). The samples were kept in the dark for 15 minutes at room temperature and absorption was measured at $734 \mathrm{~nm}$ on a spectrophotometer. All determinations were carried out in triplicate. Results were expressed as percentage inhibition (PI) as previously described for DPPH test.

\subsubsection{Ferric Reducing Antioxidant Power assay (FRAP)}

The ferric reducing power was determined according to the described method [21]. An aliquot of $0.4 \mathrm{ml}$ of each sample at different concentrations $(0.039$, $0.078,0.156,0.313,0.625,1.2$ and $2.5 \mathrm{mg} / \mathrm{ml}$ ) is mixed with $1 \mathrm{ml}$ of phosphate buffered saline (0.2 M; pH 6.6; Scharlab S.L, Spain) and $1 \mathrm{ml}$ of $1 \%$ potassium ferricyanide $\left(\mathrm{K}_{3} \mathrm{Fe}(\mathrm{CN})_{6} ; 99.8 \%\right.$, AppliChem Gmbh, Germany). The mixture was incubated at $50^{\circ} \mathrm{C}$ for $30 \mathrm{~min}$ and $1 \mathrm{ml}$ of $10 \%$ trichloroacetic acid (99.5\%, Scharlab S.L, Spain) was added. After shaked for 5 minutes, $1 \mathrm{ml}$ of the mixture was mixed with $0.2 \mathrm{ml}$ of ferric chloride (0.1\%) and left to stand in the dark for 30 minutes.

Absorbance was measured at $700 \mathrm{~nm}$; ascorbic acid was used as positive control. All determinations were carried out in triplicate. The antioxidant activity linked to the ferric reducing power of the extracts is expressed in reducing power (RP) using the following formula:

$$
R P(\%)=100\left(\frac{A_{E x}-A_{C o}}{A_{E x}}\right)
$$

$A_{E x}$ : absorbance of tested extract solution.

$A_{C o}$ : absorbance of blank sample $(\mathrm{t}=0 \mathrm{~min})$.

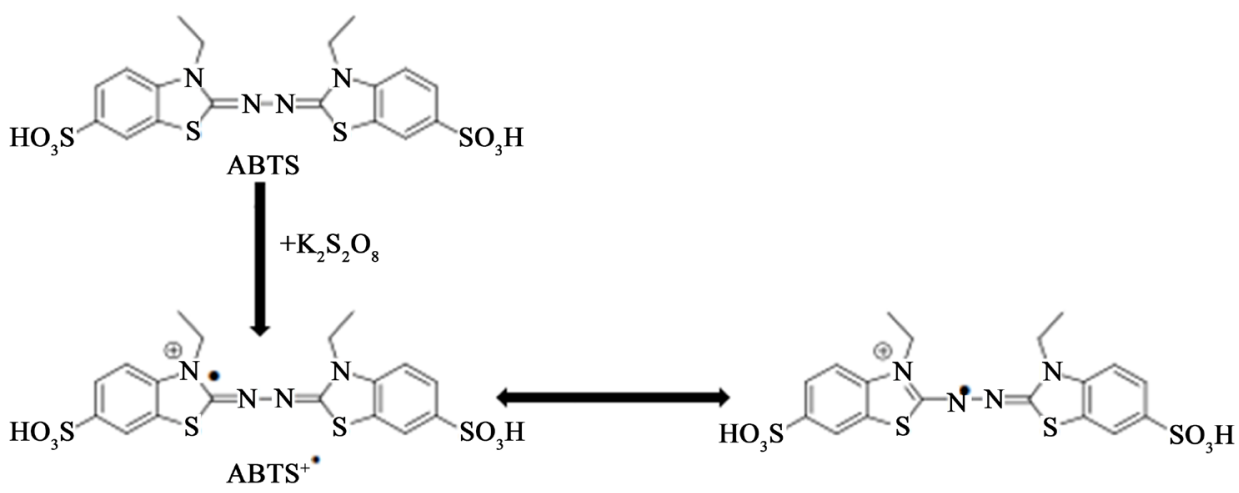

Figure $2 . \mathrm{ABTS}^{+} \cdot$ Radical formation from ABTS. 


\subsection{Statistical Analysis}

All data were subjected to one-way analysis of variance (ANOVA) with STATISTICA 7.1 to determine the significance. Means and standard errors (SE) of all data were calculated based on three replicates $(n=3)$. Comparisons among means were carried out using Tukey's HSD test at a significance level of $\mathrm{P}<0.05$. The IC50 was obtained using the Origine Pro 8.5 software.

\section{Results and Discussion}

\subsection{Phytochemical Screening}

The phytochemical screening of the various extracts revealed a significant presence of tannins, flavonoids, sterols and traces of saponosides but there is a low alkaloid content in the leaves and bark of Bauhinia rufescens Lam. These secondary metabolites were known to show medicinal activities as well as exhibiting physiological activities [22]. The presence of these phytochemical compounds in the plant materials suggests the potential medicinal value of their extracts in the prevention and/or cure of specific diseases [23]. The presence of these metabolites is revealed in the ethanolic extracts bark with the presence of quinones [13] and also in methanol stem bark extract of Bauhinia rufescens Lam [24] [25]. These metabolites are also revealed in Sclerocarya birrea [26] Sebastiania chamaelea (L.) [27] and Emilia sonchifolia (L) [28]. These compounds are frequently encountered in plant extracts such as Ziziphus mauritiana Lam, Bauhinia purpurea L. and Bauhinia variegata L. [29] [30]. These metabolites, particularly phenols and flavonoids, are the main and most common composents of plants with antioxidant activity [31].

\subsection{Total Phenolic Content}

Total phenolics constituted one of the major groups of compounds acting as primary antioxidants, it was reasonable to determine their total amount in leaves and bark extracts [16]. Gallic acid dilution series at different concentration (0.02 - $0.04-0.06-0.08-0.1-0.12-0.14 \mathrm{mg} / \mathrm{ml}$ ) was used for calibration curve in the same way as the extracts. The content of phenolic compounds (mg GAE/g DM) in all extracts, determined from regression equation of calibration curve $(\mathrm{y}=$ $\left.3.120 \mathrm{x}+0.069, \mathrm{R}^{2}=0.98\right)$ and expressed in gallic acid equivalents (GAE). The results showed that the total phenolic contents vary significantly between the extracts of the different plant parts studied as well as the extraction solvents (Figure 3). It showed that the alcoholic bark extracts have higher phenolic contents than the leaves on all the extracts with respective values of $46.75 \pm 0.002 \mathrm{mg}$ GAE/g.MS (Hydromethanol), $38.31 \pm 0.002 \mathrm{mg} \mathrm{GAE} / \mathrm{g}$ MS (hydro-acetone) and $12.64 \pm 0.002 \mathrm{mg} \mathrm{GAE} / \mathrm{g}$ MS (aqueous). On the other hand, the infused extract of the leaves had the lowest phenolic content with a value of $8.67 \pm 0.003 \mathrm{mg}$ EAG/g DM. As a result, the hydro-alcoholic extracts are richer in polyphenols compared to the aqueous extract. Our results were in line with those of Aliyu and al., found in the methanolic extract of the leaves of Bauhinia rufescens Lam 


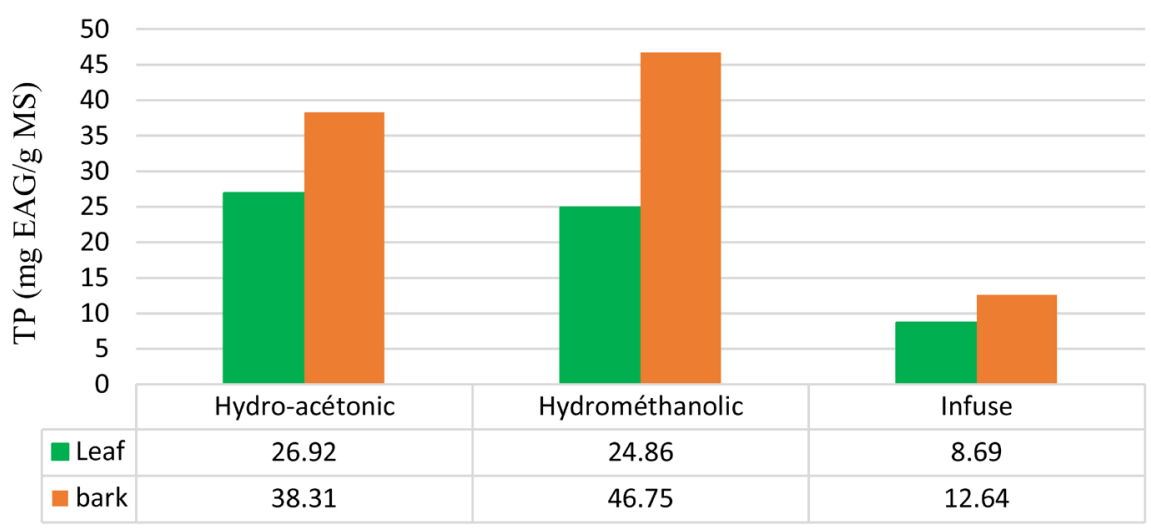

Figure 3. Total phenolic (PT) content in leaf and bark extracts.

$(68.40 \pm 0.003 \mathrm{mg}$ EAG/g) [32]. The significant presence of total phenolic in bark was found in hydro-ethanolic extracts from the leaves and bark of Piliostigma thonningii Schumach [21] and in the same extract of Sclerocarya birrea [26]. This disparity of polyphenols in different organs of the same plant was a phenomenon reported by several authors, on several Saharan medicinal plants such as Anvillea radiata Coss. \& Dur and Rumex vesicarius L. [33].

\subsection{Antioxidant Activity}

The results of the DPPH and ABTS radical tests were obtained by following the evolution of the percentage inhibition as a function of the variation in the concentration of the extracts.

\subsubsection{DPPH Radical Scavenging Assay}

The inhibition percentages showed that at all the concentrations tested, our extracts inhibit the DPPH radical in a dose-dependent manner as in the case of hydro-ethanolic extracts from the leaves and bark of Piliostigma thonningii Schumach [21]. In all the extracts tested, the bark exhibits greater activity than the leaves. Indeed, at a concentration of $2.5 \mathrm{mg} / \mathrm{ml}$, the bark extracts have a percentage inhibition of $86.55 \% \pm 0.026 \%, 85.12 \% \pm 0.025 \%$ and $84.48 \% \pm 0.020 \%$ compared to the leaves of which the PI are $85.63 \% \pm 0.02 \%, 82.3 \% \pm 0.03 \%$ and $79.52 \% \pm 0.016 \% 2 \%$ (hydro-acetonic, hydromethanolic and aqueous extracts, respectively). Ascorbic acid inhibited the DPPH radical of $94.86 \% \pm 0.01 \%$ at $1.25 \mathrm{mg} / \mathrm{ml}$ then its activity leveled up to $2.5 \mathrm{mg} / \mathrm{ml}$ (Figure 4). The percentages of inhibitions obtained are greater than those presented in the acetone extract $(71.76 \%$ at $0.825 \mathrm{mg} / \mathrm{ml})$ of Foeniculum vulgare [34]. Thus, in order to better compare the free radical activity of the various plant extracts, the $\mathrm{IC}_{50}$ was determined. At all solvents, bark extract showed the best $\mathrm{IC}_{50}$ than leave extract with values of $0.139 \mathrm{mg} / \mathrm{ml}$ (hydromethanolic), $0.354 \mathrm{mg} / \mathrm{ml}$ (hydro-acetone) and $0.84 \mathrm{mg} / \mathrm{ml}$ (aqueous) versus $0.834 \mathrm{mg} / \mathrm{ml}, 0.834 \mathrm{mg} / \mathrm{ml}$ and $0.927 \mathrm{mg} / \mathrm{ml}$ and $0.998 \mathrm{mg} / \mathrm{ml}$ respectively. Ascorbic acid had an $\mathrm{IC}_{50}$ of $0.056 \mathrm{mg} / \mathrm{ml}$. The hydro-alcoholic extracts of the bark showed the best results obtained for the PI and the $\mathrm{IC}_{50}$ by approaching the values obtained for the reference antioxidant. 


\title{
3.3.2. ABTS Radical Cation Decolourisation Assay
}

From Figure 5 it can be seen that regardless of the extraction solvent, the extracts from the leaves and bark significantly inhibited the ABTS cation radical. The inhibition percentage of the various extracts is close to ascorbic acid $(99.82 \%$ $\pm 0.014 \%$ at $2.5 \mathrm{mg} / \mathrm{ml}$ ). Indeed, at this concentration the bark extract reached its maximum activity with a PI of $99.81 \% \pm 0.012 \%$ (hydro-methanolic) compared to the leaf extracts which have a PI of $99.61 \% \pm 0.025 \%$ (Hydro-acetonic). At the highest concentration tested $(2.5 \mathrm{mg} / \mathrm{ml})$ and whatever the extraction solvent, the bark extract has the greatest PI with $99.81 \% \pm 0.012 \%$ on the ABTS radical and $86.55 \% \pm 0.026 \%$ on the DPPH radical against ascorbic acid $99.82 \% \pm$ $0.014 \%$ on the ABTS radical and $94.86 \% \pm 0.012 \%$ on the DPPH radical. Our results are better than those obtained in the methanolic extract of the leaves of Salvia sclarea $(92.9 \% \pm 0.4 \%)$ and Salvia glutinosa $(91.5 \% \pm 0.5 \%)$ [16]. The determination of the $\mathrm{IC}_{50}$ confirms a better activity of the bark compared to the leaves in the various extracts. In fact, the bark extracts exhibit $\mathrm{IC}_{50}$ of $0.472 ; 0.35$ and $0.474 \mathrm{mg} / \mathrm{ml}$ versus $0.403 ; 0.566$ and $0.937 \mathrm{mg} / \mathrm{ml}$ for the leaves (hydromethanolic, hydro-acetonic and aqueous respectively). At the same time,
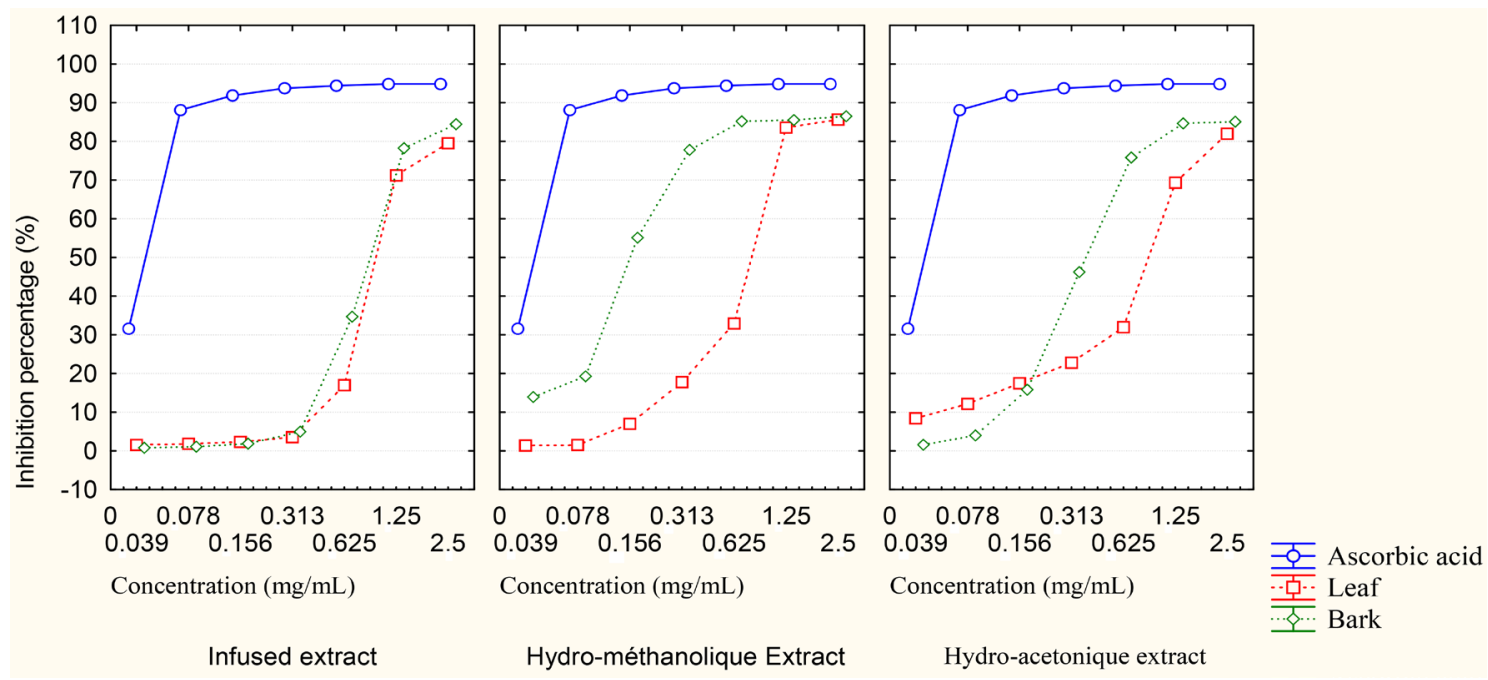

Figure 4. Inhibition percentage evolution on DPPH radical in leaf, bark and ascorbic acid.

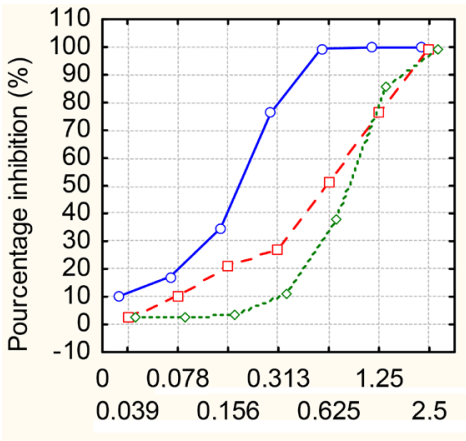

Infusioned extract

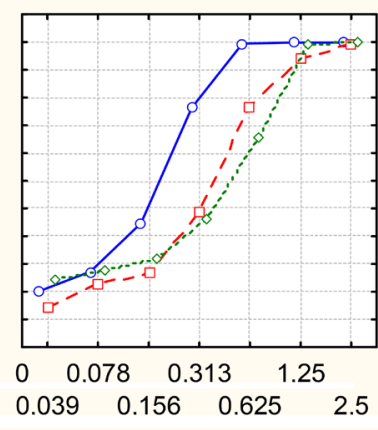

hydro-méthanolique extract

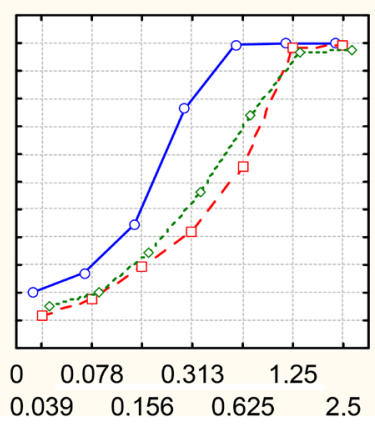

hydro-acétonique extract

\begin{abstract}
.

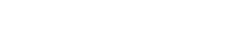


ascorbic acid gives an $\mathrm{IC}_{50}$ of $0.217 \mathrm{mg} / \mathrm{ml}$. By comparing the two methods, the $\mathrm{PI}$ and the $\mathrm{IC}_{50}$ show that the bark extracts are more active than the leaf extracts. However, ascorbic acid inhibits the ABTS radical $(99.81 \% \pm 0.014 \%)$ more than the DPPH radical $(94.86 \% \pm 0.008 \%)$. The result showed that ABTS had the highest activity when compared with all other parameters investigated They were a stable free radical, which has been widely accepted as a tool for estimating free radical scavenging activities of antioxidants. A high proportion of antioxidants in our diet prevent the body from any oxidative damage in order to maintain a better healthy condition and also to slow down aging process. Numerous studies have shown that antioxidants have protective effects on health problems. It was reported that antioxidant prevents the occurrence of diseases, like cancer and diabetes, aging and that they can also interfere with the oxidation process by reacting with free radicals, chelating, catalytic metals and also by acting as oxygen scavenger [35]. These results agree with those found on hydro-ethanolic extracts from the leaves and bark of Piliostigma thonningii Schumach [21].

\subsubsection{FRAP Test}

In analogy with the inhibitory power, the evolution of the reducing power as a function of the concentration of extracts (Figure 6) shows a strong activity of the plant. Indeed, the extracts significantly reduced the ferric ion. The hydro-methanolic, hydro-acetonic and aqueous extracts, at the maximum concentration tested $(2.5 \mathrm{mg} / \mathrm{ml})$ gave reducing powers $(\mathrm{PR})$ of the leaves and bark respectively of $61.54 \% \pm 0.01 \%-60.71 \% \pm 0.01 \%-67.90 \% \pm 0.015 \%$ and $79.29 \% \pm$ $0.004 \%$ and $60.02 \% \pm 0.026 \%-57.14 \% \pm 0.02 \%-52.73 \% \pm 0.025 \%$. At the same concentration as the extracts, ascorbic acid has a strong reducing power on ferric ion with a value of $90.70 \% \pm 0.02 \%$. Our reduction values are close to that observed $(66.67 \%)$ in the ethanolic extracts of leaves of Boerhavia elegana Choisy [36].

The results of phytochemical screening showed presence of secondary metabolites which were known to show medicinal activities. The results of total phenolic and antioxidant activity of Bauhinia rufescens Lam extracts on all three
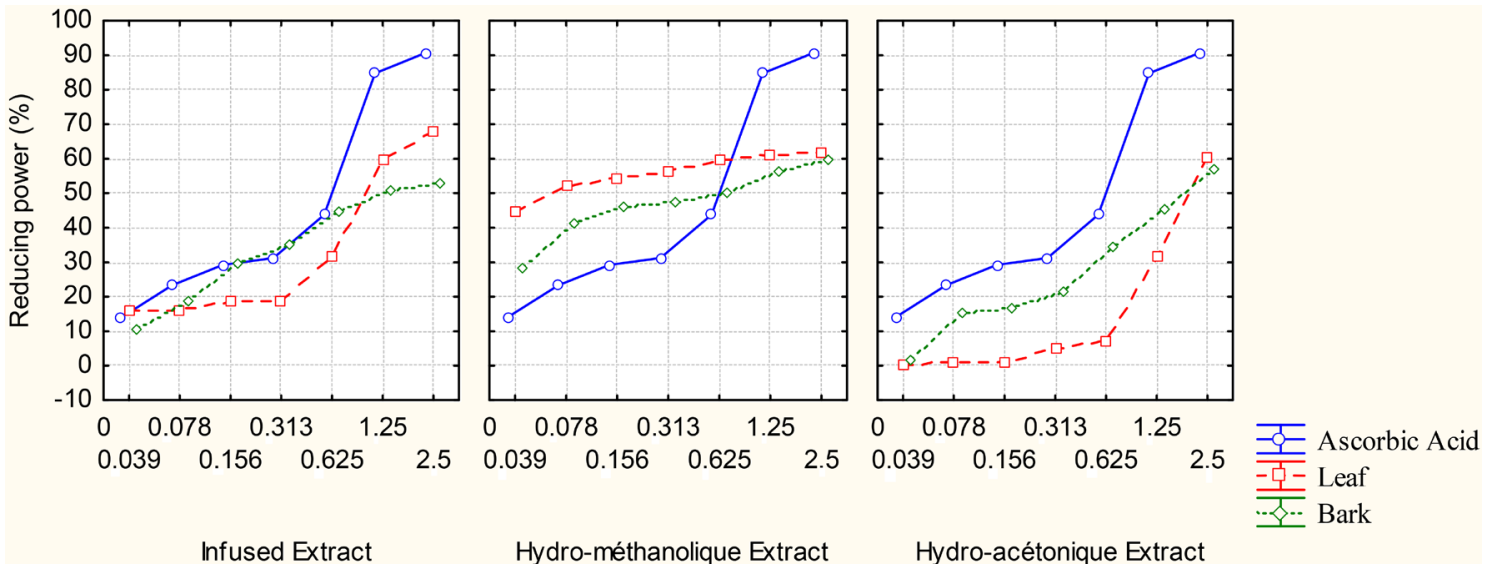

Figure 6. Reducing power evolution in leaf, bark extracts and ascorbic acid. 
tests carried out show that the hydro-alcoholic extracts of the bark are more active. Indeed, they showed higher PI and lower $\mathrm{IC}_{50}$ in the different extracts. Thus, by these 3 tests, we see that the antioxidant activity of the bark is stronger than that of the leaves. The result showed that ABTS had the highest activity when compared with all other parameters investigated. The ABTS was a stable free radical, which has been widely accepted as a tool for estimating free radical scavenging activities of antioxidants. In addition, the DPPH and the FRAP test confirmed the activity of the plant.

\section{Conclusion}

The present study has demonstrated the antioxidant activity of aqueous and hydro-alcoholic extracts of Bauhinia rufescens Lam by different methods. It shows that the hydro-alcoholic extracts of the bark have a strong antioxidant activity compared to the leaves and water. These results could constitute a solid scientific basis for the research of new natural molecular compounds, complementary to the existing chemical therapy. In fact, following the presence of secondary metabolites, the evaluation of the antioxidant activity made it possible to partially support their effect on hyperglycemia. In view of this work, biological tests with hydromethanolic and hydro-acetone extracts should provide further evidence of the hypoglycemic activity of Bauhinia rufescens Lam. A subsequent study with the aim of characterizing phenolic compounds, isolating and identifying molecules involved in antioxidant activity could provide a better understanding of the nature of the active ingredients.

\section{Conflicts of Interest}

The authors declare no conflicts of interest regarding the publication of this paper.

\section{References}

[1] Codonier-Franch, P., Boix-Garcia, L., Simo-Jorda, R., Castillo-Villaescusa, C.D., Maset-Maldonado, J. and Valls-Belles, V. (2010) Is Obesity Associated with Oxidative Stress in Children. International Journal of Pediatric Obesity, 5, 56-63. https://doi.org/10.3109/17477160903055945

[2] Halliwell, B. (2018) Free Radicals and Antioxidants in Food and in Vivo: What They Do and How They Work Section II: The Role of Free Radicals and Antioxidants. Critical Reviews in Food Science and Nutrition, 35, 7-20. https://doi.org/10.1080/10408399509527682

[3] Halliwell, B., Murcia, M.A., Chirico, S. and Aruoma, O.I. (1995) Free Radicals and Antioxidants in Food and in Vivo: What They Do and How They Work. Food Science and Nutrition, 35, 7-20. https://doi.org/10.1080/10408399509527682

[4] Sianipar, M.P., Suwarso, E. and Rosidah, R. (2018) Antioxidant and Anticancer Activities of Hexane Fraction from Carica papaya L. Male Flower. Asian Journal of Pharmaceutical and Clinical Research, 11, 81-83. https://doi.org/10.22159/ajpcr.2018.v11i3.22382

[5] Lu, Y., Hernandez, P. and Edejer, T. (2011) The World Medicines Situation 2011 
Medicine Expenditures.

[6] Antiochia, R., Gatta, T., Mazzone, E., Mannina, L. and Campanella, L. (2011) A Comparison among Three Different Analytical Methods to Test the Scavenging Properties of Different Integrators against Radicalic Stress. Pakistan Journal of Pharmaceutical Sciences, 27, 25-32.

[7] Van Der Werf, R. (2013) Evaluation du pouvoir anti-oxydant des aliments. Recherche de leurs effets modulateurs sur le stress oxydant dans le cas du diabète. Thèse de doctorat, Université de Strasbourg, Strasbourg.

[8] Sarr, S.O., Fall, A.D., Gueye, R., Diop, A., Diatta, K., Diop, N., Ndiaye, B. and Diop, Y.M. (2015) Etude de l'activité antioxydante des extraits des feuilles de Vitex doniana (Verbenacea). International Journal of Biological and Chemical Sciences, 9 , 1263-1269. https://doi.org/10.4314/ijbcs.v9i3.11

[9] Kulawik, P., Ozzogul, F., Glew, R. and Ơzogul, Y. (2013) Significance of Antioxidants for Seafood Safety and Human Health. Journal of Agricultural and Food Chemistry, 61, 475-491. https://doi.org/10.1021/jf304266s

[10] Sen, S. and Chakraborty, R. (2011) The Role of Antioxidants in Human Health. ACS Symposium Series, 1083, 1-37. https://doi.org/10.1021/bk-2011-1083.ch001

[11] Sakine, M.N.A., Mahmout, Y., Gbenou, J., Agbodjogbe, W. and Moudachirou, M. (2011) Inventaire ethnobotanique des plantes du Tchad utilisées contre le diabète: Effet anti-hyperglycémiant des extraits de Boscia senegalensis (Pers.) Lam. ex Poiret et de Colocynthis vulgaris (Schrad.). Phytothérapie, 9, 268-273.

https://doi.org/10.1007/s10298-011-0650-5

[12] Sani, I. and Bello, F. (2020) Isolation Purification and Partial Characterization of Antisnake Venom Plant Peptide (BRS-P19) from Bauhinia rufescens (LAM FAM) Seed as Potential Alternative to Serum-Based Antivenin. Journal of Biotechnology Research, 6, 18-26. https://doi.org/10.32861/jbr.64.18.26

[13] Chaibou, M., Hamadou, H. and Moussa, A.N. (2020) In Vitro Study of the Anthelmintic Effects of Ethanolic Extracts of Bauhinia rufrescens Lam. (Fabaceae) and Chrozophora brocchiana (Vis) Schweinf (Euphorbiaceae) Two Plants Used as Antiparasitic in Azawagh Area in Niger. Journal of Pharmacognosy and Phytochemistry, 9, 944-948.

[14] Ngarnougber, C., Ngaryo, F.T. and Adamou, I. (2017) Caractérisation des ligneux de la savane sahélienne à Acacia senegal (L) Willd dans la région du Guéra, Tchad. International Journal of Applied Research, 3, 600-606.

[15] Karumi, Y., Onyeyili, P.A. and Ogugbuaja, V.O. (2004) Identification of Active Principles of M. balsamina (Balsam Apple) Leaf Extract. Journal of Medical Sciences, 4, 179-182. https://doi.org/10.3923/jms.2004.179.182

[16] Miliauskas, G., Venskutonis, P.R. and Van Beek, T.A. (2004) Screening of Radical Scavenging Activity of Some Medicinal and Aromatic Plant Extracts. Food Chemistry, 85, 231-237. https://doi.org/10.1016/j.foodchem.2003.05.007

[17] World Health Organization (2013) WHO Traditional Medicine Strategy: 2014-2023. World Health Organization, Geneva, 1-4.

[18] Georgé, S., Brat, P., Alter, P. and Amiot, M.J. (2005) Rapid Determination of Poly-Phenols and Vitamin C in Plant-Derived Products. Journal of Agricultural and Food Chemistry, 53, 1370-1373. https://doi.org/10.1021/jf048396b

[19] Teodoro De Oliveira, R., Marques Junior, J., Nascimento, D.V.D. and Stefani, R. (2014) Phytochemical Screening and Comparison of DPPH Radical Scavenging from Different Samples of Coffee and Yerba Mate Beverages. International Journal of Scientific and Research Publications, 4, 1-7. 
[20] Saeed, N., Khan, M.R. and Shabbir, M. (2012) Antioxidant Activity, Total Phenolic and Total Flavonoid Contents of Whole Plant Extracts Torilis leptophylla L. BMC Complementary and Alternative Medicine, 12, Article No. 221. https://doi.org/10.1186/1472-6882-12-221

[21] Dieng, S.I.M., Fall, A.D., Diatta-Badji, K., Sarr, A., Sene, M., Mbaye, A., Diatta, W. and Bassene, E. (2017) Evaluation de l'activité antioxydante des extraits hydro-ethanoliques des feuilles et écorces de Piliostigma thonningii Schumach. International Journal of Biological and Chemical Sciences, 11, 768-776. https://doi.org/10.4314/ijbcs.v11i2.19

[22] Sofowora, A. (1993) Medicinal Plants and Traditional Medicine in Africa. 2nd Edition, Spectrum Books Limited, Ibadan, 14-34.

[23] Rasyid, Z.A., Farida, A., Daud, S.H., Wiwin, S., Wijaya, K.I. and Tangke, A.E. (2020) Bioactivities of Forest Medicinal Plants on Kutai Ethnic (Indonesia) of Tapak Leman (Hippobroma longiflora (L) G. Don). GSC Biological and Pharmaceutical Sciences, 11, 91-98. https://doi.org/10.30574/gscbps.2020.11.2.0125

[24] Usman, H., Abdulrahman, F.I., Abdu-Kaita, I. and Khan, I.Z. (2009) Phytochemical and In-Vitro Antibacterial Effects of the Partitioned Portions of Bauhinia rufescens Lam Stem Bark Extract. African Journal of Biomedical Research, 12, 210-218.

[25] Aguh, B.I., Nock, I.H., Ndams, I.S., Agunu, A. and Ukwubile, C.A. (2013) Hypoglycaemic Activity and Nephro-Protectective Effect of Bauhinia rufescens in Alloxan-Induced Diabetic Rats. International Journal of Advances in Pharmacy, Biology and Chemistry, 2, 249-255.

[26] Niang, L., Mahamat, S.A., Ayessou, N.C., Cisse, M. and Diop, C.M. (2021) Antioxidant Activity of Hydro-Acetonic, Hydro-Methanolic and Aqueous Leaf and Bark Extracts of Sclerocaria birrea L. (A. Rich.) Hochst. Food and Nutrition Sciences, 12, 429-438. https://doi.org/10.4236/fns.2021.125033

[27] Mamadou, R.S., Moussa, I., Sessou, P., Yehouenou, B., Agbangnan, P.D.C., Illagouma, A.T., Abdoulaye, A., Sohounhloué, D.C.K. and Ikhiri, K. (2014) Etude phytochimique, activités antiradicalaire, antibactérienne et antifongique d'extraits de Sebastiania chamaelea (L.) Müll. Journal de la Société Ouest-Africaine de Chimie, 37, 10-17.S.

[28] Essien, G.E., Sunday, T.P. and Udoette, I.M. (2020) In Vitro Antioxidant Analysis and Quantitative Determination of Phenolic and Flavonoid Contents of Emilia sonchifolia (L) D.C (Asteraceae) Leaf Extract and Fractions. GSC Biological and Pharmaceutical Sciences, 11, 44-52. https://doi.org/10.30574/gscbps.2020.11.2.0123

[29] Folié, N.B.Y., Kouakou, L.P.M.S., Coulibaly, K., Sanogo, R. and Koné-Bamba, D. (2017) Composition en sels minéraux et en métabolites secondaires de Ziziphus mauritiana Lam., une plante antihyperglycémiante. Journal de la Société Ouest-Africaine de Chimie, 44, 30-35.

[30] Pallavi, S.M.A. and Baheti, A.M. (2020) Pharmacognostic and Phytochemical Investigations of Bahunia Variegata Leaves (Kovidra). 4, Article ID: 000205.

[31] Khajapeer, K.V., Biswal, R. and Baskaran, R. (2018) Evaluation of Anti-CML Activity of Methanol and Aqueous Extracts of Benkara malabarica (Lam.) Tirveng Plant Leaves. International Journal of Pharmacy and Pharmaceutical Sciences, 10, 1-7. https://doi.org/10.22159/ijpps.2018v10i5.25138

[32] Aliyu, A.B., Ibrahim, M.A., Musa, A.M., Ibrahim, H., Abdulkadir, I.E. and Oyewale, A.O. (2009) Evaluation of Antioxidant Activity of Leave Extract of Bauhinia rufescens Lam. (Caesalpiniaceae). Journal of Medicinal Plant Research, 3, 563-567.

[33] Beddou, F. (2015) Etude phytochimique et activités biologiques de deux plantes 
médicinales sahariennes Rumex vesicarius L. et Anvillea radiata Coss. \& Dur. Thèse de doctorat, Biologie Cellulaire et Biochimie, Université Abou Bekr Bailked, Tlemcen, Algérie.

[34] Saheb, R. and Fethoun, M. (2015) Evaluation de l'activité antioxydant de différents extraits de Foeniculum vulgare. Mémoire de Master, biologie, Université A. MIRA-Béjaïa, Algérie, 62.

[35] Kumpulainen, J.T. and Salonen, J.T. (1999) Natural Antioxidants and Anticarcinogens in Nutrition, Health and Disease. The Royal Society of Chemistry, London, 178-187. https://doi.org/10.1533/9781845698409

[36] Ammar, A., Zhang, H. and Siddeeg, A. (2014) In Vitro Antioxidant Activity and Total Phenolic and Flavonoid Contents of Alhydwan (Boerhavia elegans Choisy). Seeds, 5, 215-220. https://doi.org/10.12691/jfnr-2-5-2 